\title{
THE NEED TO REDETERMINE THE POSITION OF ESP WITHIN EDUCATIONAL SETTING OF HIGHER EDUCATION IN SERBIA
}

ABSTRACt. English for Specific Purposes (ESP) is present at all Serbian universities, at most faculties (significantly not all), either as an obligatory or less frequently elective course at undergraduate, and sometimes at PhD studies. The subject is usually called English language, yet the content is formed as to follow the major of the faculty and is in truth ESP. However, ESP is nowhere present as a separate course at departments of English Philology. This is a paradox in itself. First, though elements of ESP might be present within other subjects at the philology departments, this is certainly not enough, and still leaves future practitioners without training to manage on their own once they find themselves in a job position that requires knowledge of specialized discourse regarding teaching it. Also, it is a paradox as for a country striving for achieving higher economical status, which implies a two-way communication of professional and scientific expertise necessitated by ESP.

KEYWORDS: ESP; higher education; education policies; education requirements.

nadezda.stojkovic@elfak.ni.ac.rs

2 danicapirsl@gmail.com 


\section{RELEVANCE OF ESP WITHIN ADULT EFL EDUCATION}

With the adult learners of English as a Foreign Language (EFL) - university students, employed professionals in need of further training or retraining, specialization, etc., General English (GE) courses are most often than not out of place. The reason for this situation is that English language is taught worldwide starting with elementary school, or before. Pupils in high schools mostly have classes of English on two parallel content tracks, they still need to perfect their GE skills, as by the time they finish that level of education they should reach B1+ level. Since most of high schools are profiled according to certain scientific and/or occupational area, pupils receive introductory instruction in English as used in that designated domain. When students reach university they already possess a significant knowledge of GE. At that stage, they start English for their scientific domain instruction that is in depth in terms of covering skills needed for their future professional and scientific communication, to imply work on relevant vocabulary, morphological elements and processes, syntactic structures, principles and models of academic speaking and writing, all emulating real-life domain settings (Mackay \& Mountford 1978). Speaking of adult learners in need of language courses, another highly relevant and frequently present group falls into the category of life-long learning, be that further education forms, in-house trainings, or else. Already established professionals needing redirection or advancement opportunities, also require courses in English that is their profession oriented and which can thus help them boost their careers.

Since today all professions, business in general, and scientific research are international, not recognizing any geographical or linguistic boundaries, education in English language is conceived as to empower students at the threshold of their careers, but also those already possessing some experience, to actively take part, contribute and be successful in their professional or scientific posts. At present, we witness globalized nature of most of business and scientific research. As such they require certain necessary linguistic abilities in order to be successful in those domains. The first ability required in order to effectively communicate in an occupational setting is the ability to use particular discourse characteristic of that specific occupational context. The second is the ability to use a more generalized set of academic skills; such may be conducting re- 
search and responding to memoranda. The third is the ability to use the language of everyday informal talk to communicate efficiently, regardless of occupational context. It is obvious that the first two directly relate to the area of English for Specific Purposes (ESP), proving that ESP needed instruction prevails. Therefore, ESP has a recognizable, and the author claims, undeniable role in the performative education that aims towards efficiency, skills and function (Stojković, Živković 2013). Because of that, ESP training is devoted to creating linguistic simulations in terms of language content and the required language skills for the specific professional situation. In other words, communicative simulation tasks are always purpose related. In this act of creating the conventions of reality, by embodying performativity approach, English for Specific Purposes can be seen as a tool that enhances skills and knowledge attained for both professional development and career advancement to comply with the needs of global economy.

\section{ATTITUDE OF LINGUISTIC DEPARTMENTS VS JOB REALITY NEEDS}

Currently, studies of English language are focused on preparing students to work with GE. As to our knowledge, no English language department in Serbia offers an introductory course in ESP. A significant number of graduated students find jobs as English teachers in primary or secondary schools, as well as in private schools of English. However, an also significant number of students go to work in firms and companies, at non-linguistic faculties, and alike positions. While during undergraduate studies they may have received some instruction as to specialized vocabulary and discourse, yet, an insightful introduction into principles and methods that would allow a future ESP practitioner independent work are missing, and once at job posts, those young graduated linguists are actually non-equipped with basic guidelines regarding linguistic work in the domain area.

Given the reasons as indicated in the previous section that in their prospective future jobs there are equal possibilities that students will need ESP as much as studied GE, English philology departments not offering ESP courses comes as a great disadvantage in the curriculum. In order to meet the requirements of employ- 
ment environment, those departments could offer at least guidelines as to how an ESP lecturer is to prepare themselves for a work in the environment that requires ESP to give students insight into how to prepare an ESP course themselves, or should they work in a company where no teaching but domain language communication is asked of them, to master the expert vocabulary and relevant morphological and syntactic structures on their own. Dealing with ESP either in a teaching or business sector necessarily means working on one's own. Yet, that can be eased should clear directions be set in the undergraduate studies. This should include introduction into the domain core vocabulary and then proceed towards teaching students how to abstract linguistic features of the given discourse working on authentic texts or speaking transcripts. Based on that, in line with the latest research extensively carried out worldwide, it would be advisable to teach compiling a corpus of vocabulary and phrases, along with the use of cutting edge technological software tools that allow for that. Next big issue is for students to learn how to effectively either use the existing teaching/learning material or create it, which is an often situation they encounter. Here they are to witness why ESP is such a profoundly demanding form of ELT, as in developing teaching material apart from all the needs analysis taught in the ESP foundation, they are to account for the complex profile of the institution for which they work. They need to plan for specific outcomes, such as pre-selected language points, and organize an informed reflective practice, on the basis of their pedagogical and methodological language awareness in order to come forward with precise requirements of the designated multifaceted, social, idiosyncratic nature of an ESP environment (Tarone \& Allwright 2005; Allwright \& Hanks 2009). In such contemporary approaches, language matters are attended as they arise, or subsequent lessons may be planned around issues that have emerged, having been requested by the learners or identified by the teacher during the episodes of interaction. Such reactive attention to language issues comes from the teacher - student interaction and not from a prescribed syllabus or a set of externally developed materials (Ellis 2012, pp. 271-306). Thus, lecturers are exposed and involved in a context-dependent nature of expert teaching, developing in themselves the ability to be reactive in their approach. By reactive we mean both to the changing trends in the target science or profession, or to learners' needs. 
Shulman (1987, p. 7) argues that teachers' knowledge base is composed of three main categories: content knowledge, general pedagogical knowledge informed by psychology, and applied pedagogy, which in our case is ESP. Content knowledge primarily concerns declarative knowledge of the English language or the knowledge of the systems of the English language and competence in it. This knowledge results from scholarship content disciplines related to English as a system (Shulman 1987, pp. 8-9), but also from the development of different components of communicative competence. Or in the words of Widdowson (2002, p. 80), subject knowledge relates to knowing how to induce students to learn. In the case of ESP, this means that the declarative, scholarly content and all the skills a teacher is taught, are to be modeled so as to fit and satisfy the needs of the target professional environment. An ESP lecturer therefore is always on a path of a continuing professional development, which is informed reflective practice. That is the teachers' professional ability to respond to linguistically sensitive, complex, context-dependent discourses, and respond to those by generating authentic interactions and learning opportunities, to be both proactive and reactive. So far, English language professionals who work in ESP in Serbia today have all had to educate themselves in order to perform well in their job environment, and not only that, but to keep enhancing their professional knowledge by constant active research engagement with the ever changing disciplinary knowledge (Dudley-Evans and St John 1998).

\section{HIGHER EDUCATION POLICIES OF UNIVERSITY INTERNATIONALIZATION}

For all the circumstances above discussed, there comes as obvious that there is much need for ESP teacher trainings. There does exist a training gap between the need for professional development and the willingness of institutions to recognize this for various reasons. However, the continuing absence of ESP courses at undergraduate level of studies at English philology departments in Serbia appears irresponsible regarding the policies of Higher Education at the national level set precisely because of the acknowledged goal to improve the economical status of the country by taking an active, 
and where possible initiative role in international business and science developments.

In order to support this, we shall hereby mention but a few of the international EU projects and National documents that clearly state education in this direction is part of crucial developmental policies. We cite SIPUS project (Strengthening of Internationalization Policies at Universities in Serbia) 544538-2013 (SIPUS, 544538-TEMPUS-1-2013-1-RS-TEMPUS-SMGR) ${ }^{3}$, whose main objectives were enabling national higher education bodies and higher education institutions to strategically manage internationalization in the provision of education, research, mobility and services, thus underpinning Serbia's accountable and complementary role in the European Higher Education and Research Area. The main outcomes included: 1. creating and implementing national legislative that has been lacking to date: Accreditation Standards for Joint and Double degrees, National Strategy of Internationalization of Higher Education and Research and National Strategy of Academic Mobility and Recognition of Degrees (in line with the Serbian Strategy of Educational Development by 2020); 2. creating and implementing individual university strategies on internationalization and academic mobility along with coherent institutional measures capable of steering internationalization, improving institutional capacities for the growing participation in international projects and strengthening the process of internal integration of Serbian universities. To relate to the language domain we refer to mid-term objectives set by the end of 2020: 1. acquisition of appropriate foreign language competences for teaching and administrative staff; 2 . increasing the number of teaching and administrative staff participating in international mobility. Long-term objectives set by the end of 2025 are: 1 . increasing the number of foreign teachers who are permanently employed at our universities and 2. having higher education institutions where the entire teaching staff is involved in some aspect of internationalization. Tempus project - Fostering University Support Services and Procedures for Full Participation in the European Higher Education Area (FUSE) 544006-20134, (Tempus project number: 544006-TEMPUS-1-2013-1-RS-TEMPUS-SMGR), is also expected to produce a number of important documents related to the topic of internationalization at the level of higher education especially in the area of the

http://www.gointernational.uns.ac.rs/

http://www.fuse.ni.ac.rs/ 
Capacity building of teaching and non-teaching staff for the full participation in EHEA. Pursuant to Article 45 Paragraph 1 of the Law on Government ("Official Gazette of RS", № 55/05, 71/05 - correction, 101/07, 65/08, 16/11, 68/12 - CC and 72/12).

Serbian Government has adopted the STRATEGY for Education Development in Serbia 2020 and this is an umbrella document ${ }^{5}$ for all other documents pertaining to higher education policies. We could also draw on the following documents: Institutional framework for development of the third mission of universities in Serbia ${ }^{6}$ and Enhancement of HE research potential contributing to further growth of the WB region ${ }^{7}$.

For that, communication professional and scientific knowledge based only on the knowledge of General English is simply insufficient and inadequate. Putting a strong emphasis on linguistic communication in professional and scientific settings, with the proper knowledge of domains vocabulary and relevant linguistic, discourse features, provides substantial, constitutive support in developing those areas that clearly lead to the desired societal changes.

REFERENCES Allwright, D. and Hanks, J. (2009). The Developing Language Learner: An Introduction to Exploratory Practice. Palgrave Macmillan.

Dudley-Evans, T. \& St John, M. (1998). Developments in ESP: A multi-disciplinary approach. Cambridge: Cambridge University Press.

Ellis, N. C. (2012). What can we count in language, and what counts in language acquisition, cognition, and use? In S. Th. Gries \& D. S. Divjak (Eds.) Frequency effects in language learning and processing (Vol. 1). (pp. 7-34). Berlin: Mouton de Gruyter.

ERASMUS PLUS PROJECT https://erasmusplus.rs/wp-content/uploads/ 2015/03/Strategy-for-Education-Development-in-Serbia-2020.pdf, accessed on August, 10, 2018.

FUSE Project http://www.fuse.ni.ac.rs, accessed on August, 10, 2018.

Hedgecook, J. S. (2003). Toward a Socioliterate Approach to Second Language Teacher Education. In The Modern Language Journal. Vol. 86, No 3. pp. 299-317.

IF4TM Project http://www.if4tm.kg.ac.rs, accessed on August, 10, 2018.

5 https://erasmusplus.rs/wp-content/uploads/2015/03/Strategy-for-Education-Development-in-Serbia-2020.pdf

6 http://www.if4tm.kg.ac.rs/

7 http://rewbc.ni.ac.rs/ 
Mackay, R., \& Mountford, A. (eds) (1978). English for Specific Purposes. London: Longman.

Piršl, D., Popovska, S. (2016). Transformative teacher training for English for specific purposes teachers. The Journal of Teaching English for Specific and Academic Purposes, Vol. 4, № 2, 435-446.

Popovska, S., \& Pirsl, D. (2013). The Role of The ESP in the Society's Value System. The Journal of Teaching English for Specific and Academic Purposes, Vol. 1, № $1,29-43$.

REWBC Project http://rewbc.ni.ac.rs, accessed on August, 10, 2018.

Shulman, L. S. (1987). Knowledge and Teaching: Foundations of the New Reform. Harvard Educational Review 57, 1-22.

Stojković, N. Živković, S. (2013). The Impact of English for Specific Purposes in the Age of Globalization. In Building Cultural Bridges in Education (pp. 77-85). Cambridge: Cambridge University Press.

Tarone, E., \& Allwright, D. (2005). Second language teacher learning and student second language learning: Shaping the knowledge base. In D. J. Tedick (Ed.), Second language teacher education: International perspectives (pp. 5-23). Mahwah, NJ, US: Lawrence Erlbaum Associates Publishers.

TEMPUS Project SIPUS http://www.gointernational.uns.ac.rs, accessed on August, 10, 2018.

Widdowson, H. (2002). Defining Issues in English Language Teaching. Oxford University Press.

\section{НАДЕЖДА СТОЈКОВИЋ}

УНИВЕРЗИТЕТ У НИШУ

ЕЛЕКТРОНСКИ ФАКУЛТЕТ

КАТЕДРА ЗА ОПШТЕОБРАЗОВНЕ ПРЕДМЕТЕ

ДАНИЦА ПИРШЛ

УНИВЕРЗИТЕТ У НИШУ

ФАКУЛТЕТ СПОРТА И ФИЗИЧКОГ ВАСПИТАҢА

КАТЕДРА ТЕОРИЈСКО-МЕТОДОЛОШКИХ ПРЕДМЕТА

РЕЗИМЕ

\section{НЕОПХОДНОСТ РЕДЕФИНИСАҢА ПОЛОЖАЈА ЕНГЛЕСКОГ ЗА ПОСЕБНЕ НА- МЕНЕ У ВИСОКОМ ОБРАЗОВАЬУ У СРБИЈИ}

Енглески за посебне намене предаје се и учи на свим универзитетима у србији, на већини факултета (не на свим), било као обавезан или ређе као изборни предмет на основним студијама, а понекад и у оквиру докторских студија. Предмет се најчешће 
зове Енглески језик, али садржај је конципиран тако да прати област студија и у суштини представља енглески за посебне намене. Међутим, енглески за посебне намене нигде не постоји као засебан предмет на департманима за англистику, што је само по себи парадокс. Мада су елементи енглеског за посебне намене присутни у оквиру других предмета на филолошким департманима, то свакако није довољно и оставља будуће наставнике без обуке да се сами сналазе када се запосле на радном месту које захтева знање језика из одређене области. Такође, ово није логично за земљу која тежи ठољем економском статусу, који подразумева двосмерну комуникацију у погледу стручне и научне експертизе.

КљУчнЕ РЕчи: енглески за посебне намене; високо образовање; политика образовања; образовне потребе.

Овај чланак је објављен и дистрибуира се под лиценцом Creative Commons Ауторство-Некомерцијално Међународна 4.0 (CC BY-NC 4.0 | https://creativecommons.org/licenses/by-nc/4.0/).

This paper is published and distributed under the terms and conditions of the Creative Commons Attribution-NonCommercial International 4.0 licence (CC BY-NC 4.0 | https://creativecommons.org/licenses/by-nc/4.0/). 